\title{
Effect of ATRA and ATO on the expression of tissue factor in NB4 acute promyelocytic leukemia cells and regulatory function of the inflammatory cytokines TNF and IL-1 $\beta$
}

\author{
Sylvie Dunoyer-Geindre ${ }^{1,2}$ - Anne-Sophie Rivier-Cordey ${ }^{1,2} \cdot$ Olga Tsopra $^{3}$. \\ Thomas Lecompte $^{3} \cdot$ Egbert K. O. Kruithof $^{1,2}$
}

Received: 7 February 2016/Accepted: 3 March 2017 /Published online: 25 March 2017

(C) The Author(s) 2017. This article is published with open access at Springerlink.com

\begin{abstract}
The characteristic hemorrhages of acute promyelocytic leukemia (APL) are caused in part by the high expression of tissue factor (TF) on leukemic cells, which also produce TNF and IL-1 $\beta$, proinflammatory cytokines known to increase TF in various cell types. Exposure of NB4 cells, an APL cell line, to all-trans retinoic acid (ATRA) or arsenic trioxide (ATO) rapidly and strongly reduced TF mRNA. Both drugs also reduced TNF mRNA, but later, and moreover increased IL- $1 \beta$ mRNA. The effect on procoagulant activity of cells and microparticles, as measured with calibrated automated thrombography, was delayed and only partial at $24 \mathrm{~h}$. TNF and IL-1 $\beta$ inhibition reduced TF mRNA and activity only partially. Inhibition of the inflammatory signaling intermediate $\mathrm{p} 38$ reduced TF mRNA by one third but increased TNF and IL-1 $\beta$ mRNA. NF-KB inhibition reduced, within $1 \mathrm{~h}, \mathrm{TF}$ and TNF mRNA but did not change IL-1 $\beta$ mRNA, and rapidly and markedly reduced cell survival, with procoagulant properties still being present. In conclusion, although we provide evidence that TNF, IL-
\end{abstract}

Electronic supplementary material The online version of this article (doi:10.1007/s00277-017-2970-5) contains supplementary material, which is available to authorized users.

Thomas Lecompte

ThomasPierre.Lecompte@hcuge.ch

1 Division of Angiology and Hemostasis, Department of Medical Specialties, University Hospital of Geneva, Geneva, Switzerland

2 Faculty of Medicine of the University of Geneva, Geneva, Switzerland

3 Division of Hematology, Department of Medical Specialties, University Hospital of Geneva, Rue Gabrielle Perret-Gentil 4, 1211 Geneva, Switzerland
$1 \beta$, and their signaling intermediates have a regulatory function on TF expression by NB4 APL cells, the effect of ATRA and ATO on TF can only partially be accounted for by their impact on these cytokines.

Keywords Acute promyelocytic leukemia · Tissue factor · Tumor necrosis factor $\cdot$ Interleukin 1 beta $\cdot$ All-trans retinoic acid $\cdot$ Arsenic trioxide

\section{Introduction}

The persistent and worrisome hallmark of acute promyelocytic (M3) leukemia (APL) is the high risk of severe, often fatal, bleeding complications [1-6]. Pathogenesis of the coagulopathy is complex and includes an insufficient production of platelets, as well as disseminated intravascular coagulation (DIC) [2, 6-9], caused, at least in part, by tissue factor (TF) expressed on the leukemia cells and on leukemia cell-derived microparticles expressing $\mathrm{TF}$ and procoagulant phosphatidylserine on their surface [10-14]. Fibrinolysis, mediated by t-PA bound to annexin 2 on the leukemia cell, is another important factor contributing to hemorrhagic complications [15].

Treatment of APL patients with all-trans retinoic acid (ATRA) or arsenic trioxide (ATO) leads, over a period of 1 to 3 weeks, to normalization of plasma concentrations of D-dimers and thrombin-antithrombin complexes [7, 8, $16,17]$ and of TF mRNA in patient-derived bone marrow cells $[8,16,18]$. Studies performed with cultured bone marrow cells from APL patients revealed that exposure to ATRA reduced cell-associated procoagulant activity [19]. Experiments using NB4 cells, an APL cell line that presents the characteristic 15;17 chromosomal translocation, showed that exposure to ATRA or ATO resulted in a 
reduction of TF mRNA and antigen [18, 20-22] as well as of TF activity [12]. However, as therapy by ATRA or ATO (mostly) leads to APL cell apoptosis and thus generation of microparticles $[10,23]$, it is possible that ATRA-mediated differentiation of APL cells leads to a transient increase in procoagulant activities, despite its downregulating effect on TF mRNA [13]. A further factor that has to be taken into account is the production by APL cells of proinflammatory cytokines, such as TNF and IL$1 \beta[24,25]$. This may be of clinical relevance because these cytokines are capable, among other properties, of increasing TF production in monocytes and endothelial cells and, considering that NB4 cells express TNF receptor 1 [26], could also contribute to TF production by APL cells.

In the present study, we used NB4 cells to investigate in more detail the time course of the effects of ATRA and ATO on TF activity and on expression of the proinflammatory cytokines TNF and IL-1 $\beta$. In addition, we investigated to what extent TF production by NB4 cells depends on TNF and IL$1 \beta$ they also produce and whether it is affected by interfering with the inflammatory signaling intermediates p38, jun kinase, and NF-kB. We observed that exposure of NB4 cells to ATRA led within $1 \mathrm{~h}$ to a reduction of TF mRNA and to a reduction of TNF mRNA but only after $6 \mathrm{~h}$. Exposure to ATO also induced a reduction of TF and TNF mRNA, which was detectable only after 3 and $6 \mathrm{~h}$, respectively. Both ATRA and ATO increased IL-1 $\beta$ mRNA several fold. A partial reduction in TF antigen and TF activity was evident only after $24 \mathrm{~h}$ of ATRA or ATO treatment. Inhibition of TNF and, to a lesser extent, of IL-1 $\beta$ only partially reduced TF mRNA. Inhibition of $\mathrm{p} 38$ reduced TF mRNA but strongly increased TNF and IL- $1 \beta$ mRNA, while inhibition of JNK had no effect on TF and TNF mRNA but reduced IL- $1 \beta$ mRNA. Inhibition of NF- $\kappa$ B reduced TF and TNF mRNA in NB4 cells with more than $50 \%$ within $1 \mathrm{~h}$ but also reduced cell survival with a half-life of approximately $6 \mathrm{~h}$.

\section{Materials and methods}

\section{Reagents}

ATRA and ATO were from Sigma-Aldrich. Adalimumab (Humira®), a TNF activity-blocking antibody, was from Abbott Laboratories, and Anakinra (Kineret $\left.{ }^{\circledR}\right)$, an IL-1 receptor antagonist, was from Swedish Orphan Biovitrum. BAY117085 , an inhibitor of NF- $\mathrm{KB}$, was from Biomol. The p38 inhibitors SB203580, SB202190, and Birb796 were from Sigma-Aldrich, Biomol, and Axon Medchem, respectively. The jun kinase inhibitor SP600125 was from Tocris Biosciences.

\section{Cell lines used}

NB4 APL and HL-60 acute myeloid leukemia cells were obtained from the German Collection of Microorganisms and Cell Cultures (http://www.dsmz.de). NB4 cells contain the 15;17 chromosomal translocation and are used as a standard model for investigations on the mechanisms of cellular responses of APL cells, whereas HL60 cells lack the 15;17 chromosomal translocation. NB4 and HL60 cells were cultured in RPMI 1640 medium (Gibco) + 10\% fetal bovine serum (Pan Biotech) and 1\% of penicillin/streptomycin. U937-PR9 cells, stably transfected with DNA encoding the PML-RAR $\alpha$ fusion protein under control of the metallothionin promoter, as well as the corresponding control U-937MT cells [27], were a kind gift from Prof. P.G. Pelicci (Department of Experimental Oncology, European Institute of Oncology, 20141 Milan, Italy). The cells were cultured at a density of $10^{6}$ cells $/ \mathrm{ml}$ in RPMI 1640 medium $+10 \%$ fetal bovine serum and $1 \%$ of penicillin/streptomycin. Cells were used for up to ten passages after having been received. They were isolated by centrifugation for $5 \mathrm{~min}$ at $300 \times \mathrm{g}$ and $4{ }^{\circ} \mathrm{C}$ and cell-derived microparticles by centrifugation of the cell supernatant for $5 \mathrm{~min}$ at $1500 \times \mathrm{g}$ to remove cell debris followed by a further centrifugation for $30 \mathrm{~min}$ at $20,000 \times \mathrm{g}$. Cells and microparticles were suspended in Dulbecco's phosphatebuffered saline (Gibco, cat. no. 14190-094). Coagulation studies with the supernatant prepared as just above described will be referred to as "microparticle-associated coagulant activities." Those studies were thus performed with both cell suspension $(50,000 / \mathrm{ml})$ and microparticles (suspended in an equivalent volume as the cells).

\section{Quantitative reverse transcriptase real time PCR (qPCR) assay for TF, TNF, and IL-1 $\beta$ mRNA}

Total cellular RNA was isolated using the TRIzol reagent (Invitrogen) and reverse transcribed using the Improm-II reverse transcriptase system from Promega. Thereafter, qPCR was performed as described previously [28] using the $\Delta \Delta \mathrm{CT}$ method and GAPDH as the control housekeeping gene. The following forward and reverse primer sequences, respectively, were used for mRNA quantification by qPCR:

GAPDH: GGTGAAGGTCGGAGTCAAC and CCATGGGTGGAATCATATTG

TF: CTACTGTTTCAGTGTTCAAGCAGT and CAGTGCAATATAGCATTTGCAGTAGC

TNF: CCCAGGCAGTCAGATCATCTTC and AGCTGCCCCTCAGCTTGA

IL-1 $\beta$ : AAACAGATGAAGTGCTCCTTCCAGG and TGGAGAACACCACTTGTTGCTCCA

CD11c: AGAGCTGTGATAAGCCAGTTCC and AATTCCTCGAAAGTGAAGTGTGT 


\section{Flow cytometry analysis}

$\mathrm{TF}$ and CD11c, a marker of granulocytic differentiation, were analyzed with flow cytometry using a BD Biosciences Accuri C6 flow cytometer. APC-labeled antibodies to TF (CD142) and its isotype (IgG1kappa) matched APC-labeled control antibodies (IgG-APC) were from eBioscience (cat. nos. 171429 and 17-4714, respectively) and phycoerythrin-labeled antibodies to CD11c and its isotype (IgG1kappa) matched PE-labeled control antibodies (IgG-PE) were from BD Pharmingen (cat. nos. 555392 and 555749, respectively). The cells were first washed in phosphate-buffered saline (PBS) $+1 \%$ bovine serum albumin (PBS/BSA) and $0.01 \%$ sodium azide. Then, 200,000 cells were incubated for $30 \mathrm{~min}$ at room temperature with $0.6 \mu \mathrm{lgG}-\mathrm{APC}+20 \mu \mathrm{l}$ IgG-PE or with $5 \mu \mathrm{lCD} 142-\mathrm{APC}+20 \mu \mathrm{lCD} 11 \mathrm{c}-\mathrm{PE}$ in a total volume of $50 \mu \mathrm{l}$ PBS/BSA. Thereafter, $500 \mu \mathrm{l}$ of PBS/BSA was added and the cells centrifuged for $5 \mathrm{~min}$ at $200 \times g$ and $4{ }^{\circ} \mathrm{C}$. The cells were washed once with $500 \mu \mathrm{l}$ of PBS/BSA and resuspended in $200 \mu \mathrm{l}$ PBS/BSA. The cell suspension was stored on ice in the absence of light. Five minutes before flow cytometry analysis, $5 \mu \mathrm{l}$ of $1 \mathrm{mg} / \mathrm{ml}$ of 7 -amino actinomycin (7-AAD; R\&D systems) was added to exclude dead cells from analysis.

\section{Coagulation assays}

TF activity was quantified with a factor FXa generation assay [29], and overall coagulant activity was assessed with a thrombin generation assay (calibrated automated thrombography) [30]. The contribution of TF to activities measured in those assays was explored by comparing activities in the presence and absence of $10 \mu \mathrm{g} / \mathrm{ml}$ of a murine monoclonal anti-TF antibody (Ref 4509, Sekisui Diagnostics). This anti-TF antibody concentration was shown to be sufficient to completely block factor FXa generation activity on LPS-treated human endothelial cells [31].

Factor Xa generation assay In short, hundred microliters of a suspension of cells $(50,000 / \mathrm{ml})$ or microparticles (suspended in an equivalent volume as the cells) was incubated with $5 \mu \mathrm{l}$ of human coagulation factor X (at $3.4 \mu \mathrm{M}$; HCX-0500, Haematologic Technologies Inc.) and $10 \mu \mathrm{l}$ of factor VIIa (at $50 \mathrm{nM}$, Novoseven, Novo Nordisk). The samples were incubated for 15 min at $37^{\circ} \mathrm{C}$ and further FXa generation stopped by addition of $50 \mu \mathrm{l}$ of $15 \mathrm{mM}$ EDTA. Thereafter, $50 \mu \mathrm{l}$ of the FXa chromogenic substrate SFXA-11 (Hyphen Biomed) was added at $3.9 \mathrm{mM}$ and the mixture incubated for a further $15 \mathrm{~min}$ at $37{ }^{\circ} \mathrm{C}$. After addition of $100 \mu \mathrm{l}$ of $1 \mathrm{M} \mathrm{H}_{2} \mathrm{SO}_{4}$, the absorbance was read at $405 \mathrm{~nm}$ and compared to that of a standard curve made using different concentrations of bovine factor FXa (Hyphen Biomed). Results are expressed as relative to the activity of unexposed NB4 cells.
Calibrated automated thrombography (CAT) assay This was done according to the manufacturer's instructions using reagents and procedures provided by Diagnostica Stago. Suspensions of cells $(50,000 / \mathrm{ml})$ or microparticles (suspended in an equivalent volume as the cells) were mixed with normal plasma and fluorescence development measured with a Fluoroskan Ascent (Thermo electron corporation) microplate fluorimeter and analyzed using Thrombinoscope ${ }^{\mathrm{TM}}$ software (Diagnostica Stago).

\section{Statistical analysis}

Data are presented as means \pm standard error of the mean (SEM). The significance of differences was assessed using the paired Student's $t$ test.

\section{Results}

\section{Effect of ATRA and ATO on mRNA levels of TF, TNF, IL-1 $\beta$, and CD11c in NB4 and HL-60 cells}

The inflammatory cytokines TNF and IL- $1 \beta$ are known to be produced by APL cells and are capable of increasing TF expression in some cell types. We first investigated in NB4 cells to what extent ATRA and ATO, which are nowadays standard therapeutics in APL patients, modified mRNA levels of TF, $\mathrm{TNF}$, and IL-1 $\beta$. In preliminary concentration response experiments we determined after 24-h incubation, the concentrations at which ATRA and ATO attained their maximal effect.

With ATRA, in NB4 cells, we observed a maximal effect after $24 \mathrm{~h}$ at $0.5 \mu \mathrm{M}$. At this concentration, TF mRNA was reduced by $92 \pm 2 \%$ (mean \pm SEM, $n=4)$ and TNF mRNA by $88 \pm 1 \%$. A time-response curve performed with $0.5 \mu \mathrm{M}$ ATRA showed that ATRA attained its maximal effect on TF mRNA already within $1 \mathrm{~h}$, whereas its inhibitory effect on TNF mRNA was detectable only after $4 \mathrm{~h}$ and attained its maximal effect of more than $80 \%$ inhibition only after $15 \mathrm{~h}$ (Fig. 1, left). In contrast with its inhibitory effect on TF and TNF mRNA, $0.5 \mu \mathrm{M}$ ATRA increased IL- $1 \beta$ mRNA by $4.3 \pm 0.7$-fold, already within $4 \mathrm{~h}$.

To assess whether these results were specific to NB4 cells, the effects of ATRA on the expression of TF, TNF, and IL-1 $\beta$ were also investigated in HL-60 cells, another myelocytic leukemic cell line widely used for such in vitro studies. After 3-h ATRA treatment, TF mRNA was reduced by at most by $35 \%$, whereas no changes in TNF mRNA were observed (not shown). Levels of IL-1 $\beta$ mRNA in HL-60 cells were below the detection limit.

With ATO and NB4 cells, we observed a maximal effect at $5 \mu \mathrm{M}$. At this concentration, both TF and TNF mRNA were reduced by $60 \%$ after $6 \mathrm{~h}$ incubation. No further reduction was 
observed at $24 \mathrm{~h}$ for TNF mRNA, whereas TF mRNA was almost undetectable after $24 \mathrm{~h}$ (Fig. 1, right). ATO at $5 \mu \mathrm{M}$ increased IL-1 $\beta$ mRNA levels up to threefold but only after 24 h. In HL-60 cells, ATO increased TF mRNA by up to twofold (not shown) and had no effect on TNF mRNA.

To determine whether the effects of exposure of NB4 cells to ATRA and ATO were correlated with their differentiation, we performed mRNA analysis and flow cytometry analysis for CD11c, a marker for promyelocytic cell differentiation. Exposure to ATRA resulted in a gradual increase in CD11c mRNA (fourfold at $6 \mathrm{~h}$ and tenfold at $24 \mathrm{~h}$ ) (Fig. 1, left). $\mathrm{CD} 11 \mathrm{c}$ antigen at the cell surface, as assessed by flow cytometry, was only detectable after 16 and $24 \mathrm{~h}$ of ATRA treatment (not shown). The effect of ATRA on TF precedes its effect on cell maturation, as the maximal effect of ATRA on TF mRNA was obtained within $1 \mathrm{~h}$. In contrast to ATRA, and as expected, ATO had no effect on CD11c mRNA (Fig. 1, right) and CD11c antigen (not shown).

\section{Effect of the PML-RAR $\alpha$ fusion protein on expression of TF, TNF, and IL-1 $\beta$}

As ATRA and ATO are both capable of reducing the PMLRAR $\alpha$ fusion protein [32], we investigated the effect of
Fig. 1 Time course of the effect of ATRA or ATO on mRNA levels of TF, TNF, IL- $1 \beta$, and CD11c in NB4 cells. NB4 acute promyelocytic leukemia cells were exposed for the indicated time periods to $0.5 \mu \mathrm{M}$ ATRA (left) or $5 \mu \mathrm{M}$ ATO (right). Levels of mRNA were quantified by qPCR and expressed relative to that of the corresponding mRNA in control (untreated cells, incubated $24 \mathrm{~h}$ in medium alone) NB4 cells. The results are the means \pm SEM of at least four independent experiments
ATRA
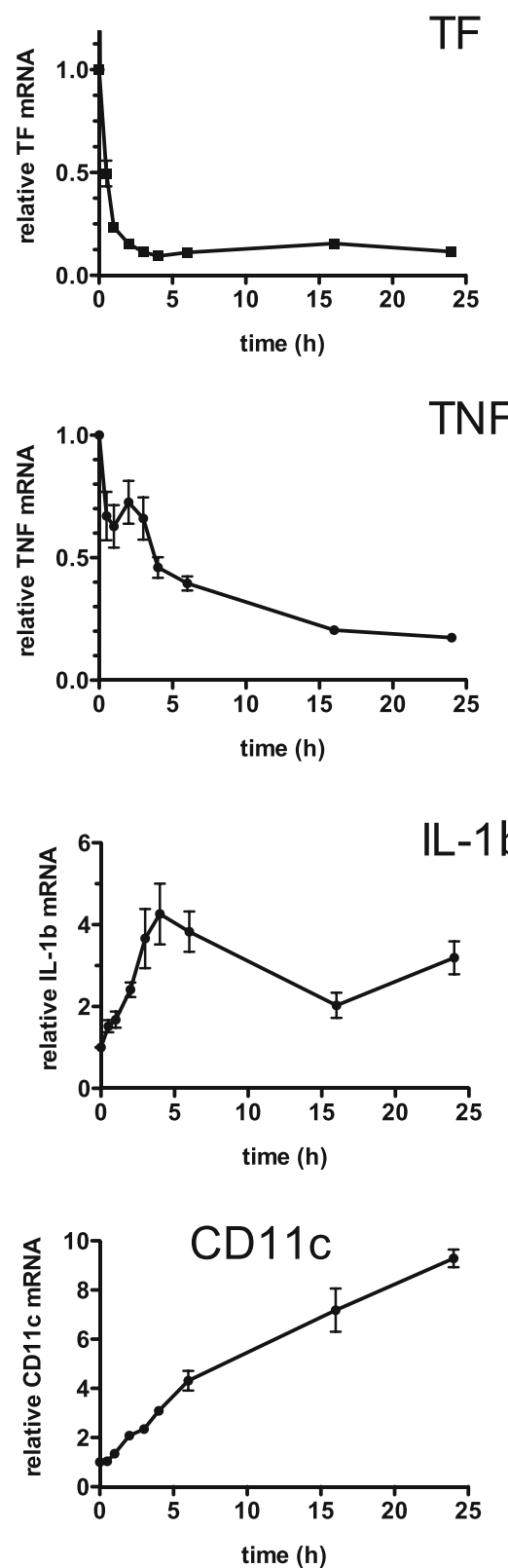

ATO

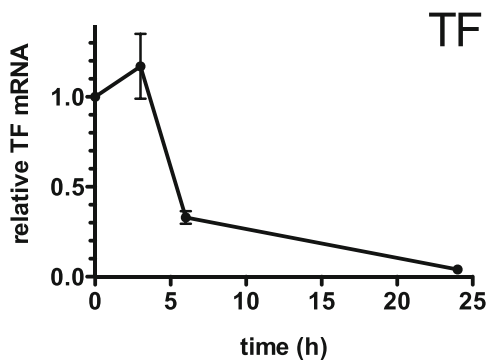

TNF
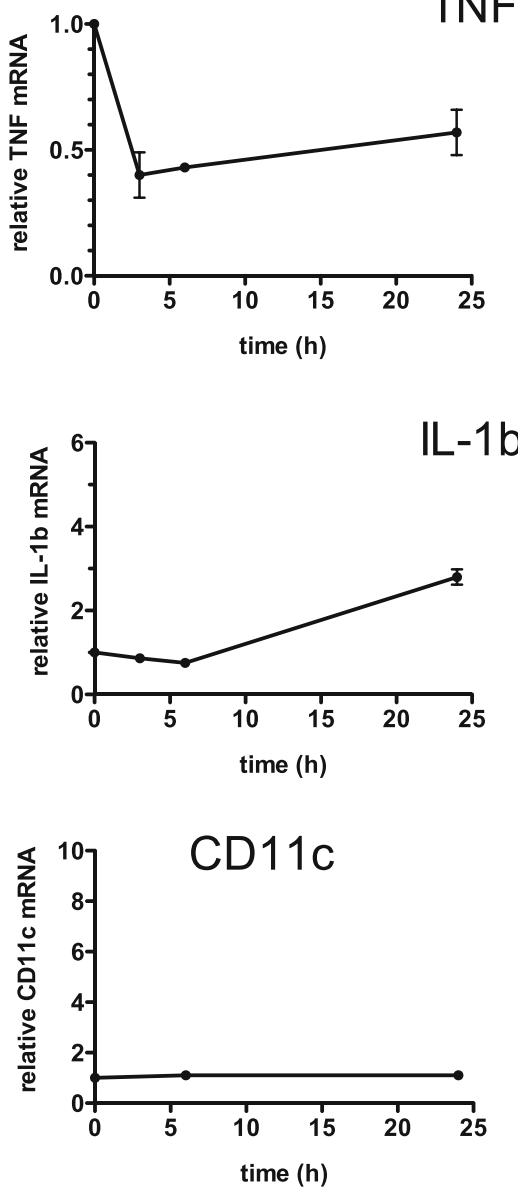
specifically increasing PML-RAR $\alpha$ on mRNA levels of TF, TNF, and IL-1 $\beta$. For this, we used the U937-PR9 cell line in which PML-RAR $\alpha$ production is under control of the metallothionin promoter. In the presence of $100 \mu \mathrm{M}$ of $\mathrm{Zn}^{2+}$, these cells produce PML-RAR $\alpha$, whereas this fusion protein is not made in the absence of $\mathrm{Zn}^{2+}$ [27]. This allows thus the direct comparison of the effect of PML-RAR $\alpha$ on expression of TF, TNF, and IL-1 $\beta . \mathrm{Zn}^{2+}$ treatment of U937-PR9 cells resulted in an almost tenfold increase of both TF and TNF mRNA after $48 \mathrm{~h}$ (Fig. 2, left and center). At this time point, a threefold increase in IL-1 $\beta$ mRNA was observed (Fig. 2, right). No changes in TF and TNF mRNA were observed after $\mathrm{Zn}^{2+}$ treatment of the control U937-MT cell line, which is stably transfected with an empty plasmid containing a metallothionin promoter (data not shown). We then studied whether ATO, which inactivates the PML-RAR $\alpha$ fusion protein, had an effect on TF mRNA in U937-PR9 cells pretreated

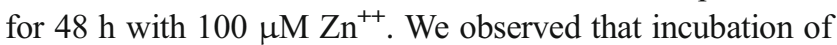
these cells with $1 \mu \mathrm{M}$ or $5 \mu \mathrm{M}$ ATO reduced TF mRNA by $59 \pm 7 \%$ and $89 \pm 2 \%$ for $5 \mu \mathrm{M}$ ATO, respectively (mean $\pm \mathrm{SE}$ of three independent experiments).

\section{Effect of ATRA and ATO on TF antigen and activity of NB4 cells and of their microparticles}

Flow cytometry analysis was performed to assess TF antigen at the NB4 cell surface. We observed that both ATRA and ATO reduced TF antigen. A $26 \%$ and $19 \%$ decrease in TF antigen was observed after a 6-h exposure to ATRA or ATO, respectively. After $24 \mathrm{~h}$ of exposure to ATRA or ATO, hardly any TF antigen was seen at the NB4 cell surface. Indeed, the flow cytometry signal for TF was only marginally higher than the signal obtained with isotype-matched control antibodies (Fig. 3a).

We then analyzed the effects of ATRA and ATO on procoagulant activities expressed on NB4 cells and on NB4 cell-derived microparticles. We first determined the contribution of TF to NB4 cell or microparticle-associated FXa generation activity. We observed that co-incubation with $10 \mu \mathrm{g} / \mathrm{ml}$ of blocking anti-TF monoclonal antibody reduced
NB4 cell- and microparticle-associated activity by $79 \%$ and $100 \%$, respectively. A 3-h exposure to $0.5 \mu \mathrm{M}$ ATRA reduced cell-associated FXa generation activity by $22 \%$, whereas ATO had no effect (Fig. 3b). No differences in microparticleassociated activities were observed at this time point (Fig. 3c). After 24-h exposure, NB4 cell-associated activity was reduced by $69 \pm 19 \%(p<0.001)$ by ATRA and by $52 \pm 12 \%(p<0.002)$ by ATO (Fig. 3b). At this time point, ATRA and ATO reduced microparticle-associated TF activity by $50 \pm 29 \%(p<0.001)$ and $47 \pm 28 \%(p<0.002)$, respectively (Fig. 3c).

We also analyzed with the CAT assay the effect of ATRA and ATO on procoagulant activities of NB4 cells and NB4 cell-derived microparticles. This assay takes into account the contribution of TF, anionic phospholipids, and any other potential players, even inhibitors such as thrombomodulin, expressed by NB4 cells [20, 33, 34], to thrombin generation [35], and is a more global and relevant assay than the FXa generation assay. With a 24 -h incubation with ATRA, we observed an increase in the lag time (LT = time elapsed before the thrombin burst) and a decrease in the slope of the ascending part of the curve (= a reduction in the presence of anionic phospholipids), the peak height (peak = maximal thrombin concentration) and of the area under the curve (referred to as "endogenous thrombin potential"-ETP = total amount of thrombin action); this was observed both for cells and microparticles (Fig. 4a, b). Exposure to ATO also increased the lag time but to a lesser extent than ATRA (Fig. 4b) and also reduced peak height, but its effect on the area under the curve was minimal.

\section{Effect of inhibition of TNF or IL-1 $\beta$ on TF mRNA and procoagulant activity of NB4 cells}

The reduction in TF and TNF mRNA in ATRA- or ATOtreated NB4 cells, as well as the known ability of TNF to increase TF in monocytes and endothelial cells, raised the question as to a possible contribution of TNF to TF expression by these cells. Incubation of NB4 cells for $24 \mathrm{~h}$ with adalimumab, an inhibitory monoclonal antibody to TNF,
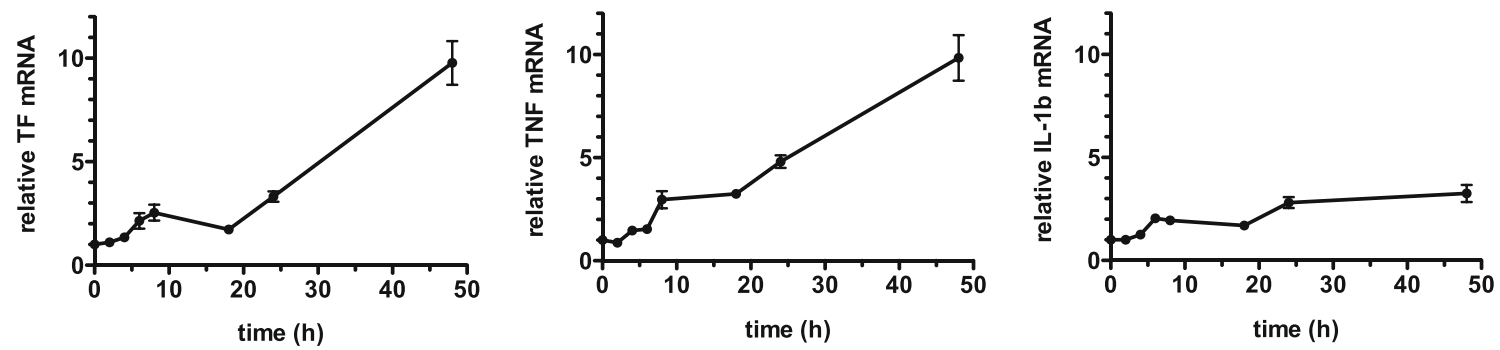

Fig. 2 Effect of the PML-RAR $\alpha$ fusion protein on mRNA levels of TF, TNF, and IL- $\beta$ in U-937-PR9 cells. U937-PR9 cells, in which PML$\mathrm{RAR} \alpha$ production is under control of the metallothionin promoter, were incubated for up to $48 \mathrm{~h}$ with $100 \mu \mathrm{M}$ of $\mathrm{Zn}^{2+}$ to stimulate the production of the PML-RAR $\alpha$ fusion protein. Levels of mRNA for TF (left), TNF (center), and IL-1 $\beta$ (right) were quantified by qPCR and expressed relative to that of the corresponding mRNA in control (untreated cells, incubated $24 \mathrm{~h}$ in medium alone) U937-PR9 cells. The results are the means \pm SEM of at least four independent experiments 

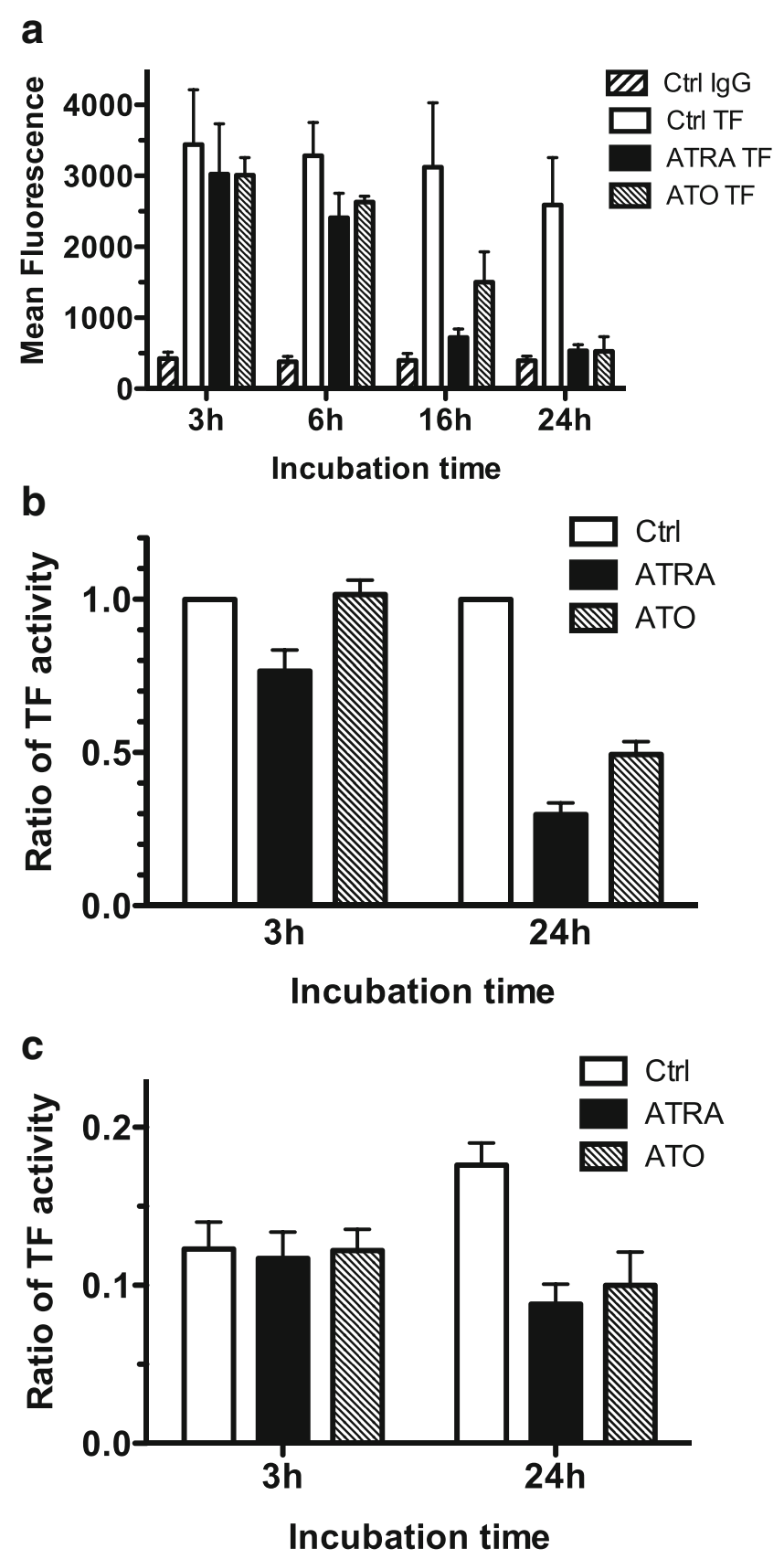

Fig. 3 Effect of ATRA and ATO on TF antigen and activity of NB4 cells and NB4-cell-derived microparticles. a NB4 cells were exposed for the indicated time periods to $0.5 \mu \mathrm{M}$ ATRA or $5 \mu \mathrm{M}$ ATO. After the indicated time periods, TF antigen on the NB4 cell surface was analyzed by flow cytometry. "Ctrl IgG" are flow cytometry results obtained with an APC-labeled isotope matched control antibody and "Ctrl TF" are flow cytometry results obtained with APC-labeled antibodies on unexposed NB4 cells. Results are expressed as means \pm SEM of at least four independent experiments. The reduction in TF antigen at $24 \mathrm{~h}$ in the ATRA or ATO treated cells with respect to the

resulted in a concentration-dependent reduction in TF mRNA with a maximum of $28 \%$ at $10 \mu \mathrm{g} / \mathrm{ml}$ (Fig. 5). Increasing unexposed cells (Ctrl TF) was significant with $p$ values below 0.01. b and c TF activity of NB4 cells (b) or NB4 cell-derived microparticles (c) after 3 or $24 \mathrm{~h}$ exposure to $0.5 \mu \mathrm{M}$ ATRA or $5 \mu \mathrm{M}$ ATO. All the results of $\mathbf{b}$ and $\mathbf{c}$ are expressed as ratio of $\mathrm{TF}$ activity as compared to that of unexposed NB4 cells at the same time point. The results are the means \pm SEM of five to seven independent experiments. The reduction in TF activity at $24 \mathrm{~h}$ in the ATRA- or ATO-treated cells or derived microparticles with respect to the unexposed cells (Ctrl) or their microparticles was significant with $p$ values below 0.01

adalimumab concentrations to $100 \mu \mathrm{g} / \mathrm{ml}$ did not lead to a further reduction in TF mRNA (data not shown). 


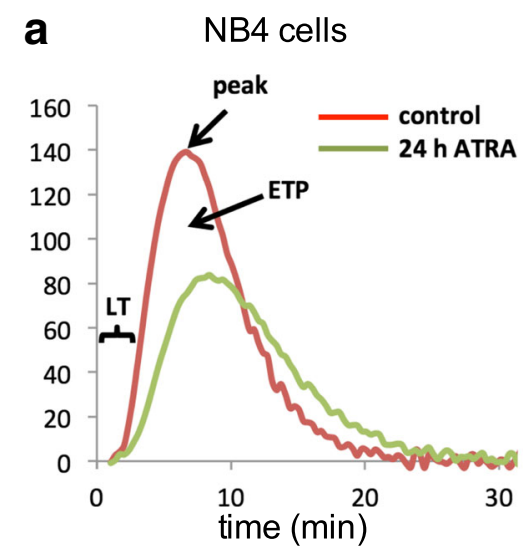

NB4 microparticles
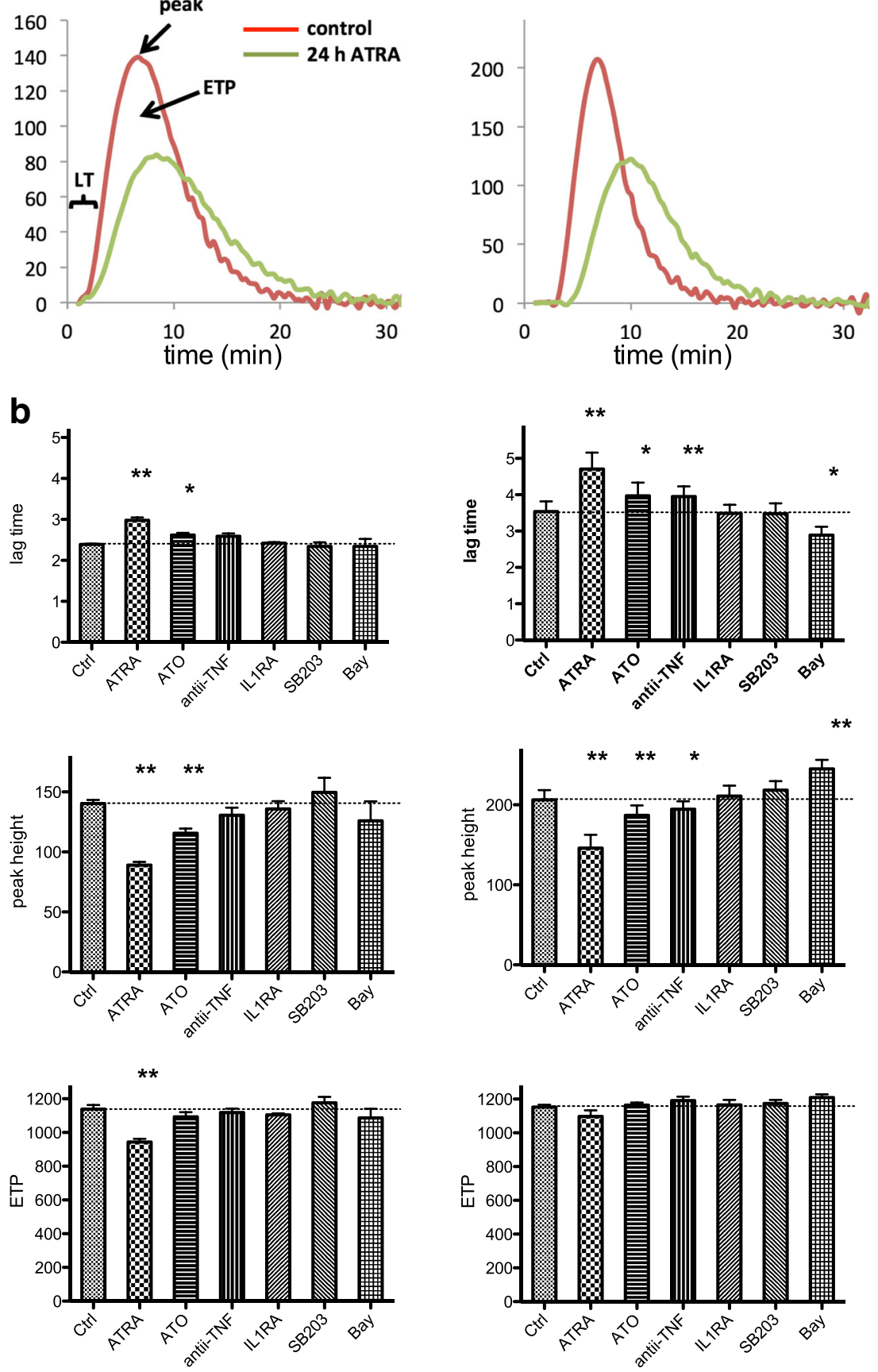

Fig. 4 Effect of the agents investigated on procoagulant activities of NB4 cells or NB4 cell-derived microparticles as assessed with calibrated automated thrombography. NB4 cells were exposed for $24 \mathrm{~h}$ to the indicated agent and procoagulant activities of NB4 cells (left) or NB4 cell-derived microparticles (right) assessed with the CAT assay. a Typical thrombogram (CAT) of unexposed $(\mathrm{red})$ or ATRA treated (green) NB4 cells or NB4 cell-derived microparticles. LT lag time (= time elapsed before thrombin burst), peak height (= maximal thrombin concentration), and ETP: area under the curve (= total amount of

thrombin action). b Histograms of results obtained regarding lag time, peak height, and ETP with cells (left) or cell-derived microparticles (right) obtained from NB4 cells exposed to $0.5 \mu \mathrm{M}$ ATRA, $5 \mu \mathrm{M}$ ATO, $10 \mu \mathrm{g} / \mathrm{ml}$ of adalimumab (anti-TNF: a TNF inhibitory antibody), $10 \mu \mathrm{g} / \mathrm{ml}$ of anakinra (IL1RA: an IL-1 receptor antagonist), $10 \mu \mathrm{M}$ SB203580 (SB203: a p38 inhibitor), or $100 \mu \mathrm{M}$ BAY11-7085 (Bay: a $\mathrm{NF}-\mathrm{kB}$ inhibitor). Results are presented as the means $\pm \mathrm{SEM}$ of four to six independent experiments. Differences were analyzed using the paired Student's $t$ test. $(* p<0.05$ and $* * p<0.01)$

As NB4 cells also produce IL-1 $\beta$, we investigated, in addition, the effect of inhibiting this inflammatory cytokine.

Incubation of NB4 cells with the IL- $1 \beta$ receptor antagonist anakinra resulted in a reduction of $20 \%$ at most (Fig. 5). 


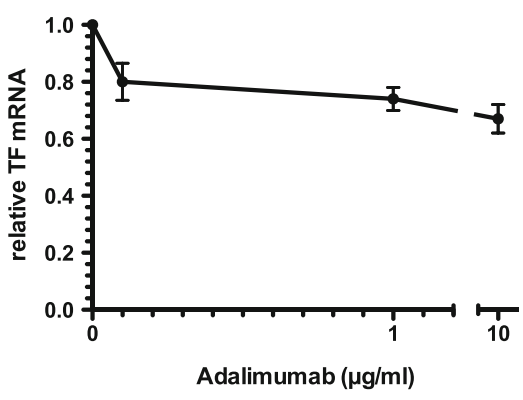

Fig. 5 Effect of inhibition of TNF or IL-1 $\beta$ on TF mRNA levels in NB4 cells. NB4 cells were exposed for $24 \mathrm{~h}$ to various concentrations of adalimumab (a TNF inhibitory antibody) or anakinra (an IL-1 receptor antagonist) and TF mRNA levels were quantified by qPCR and expressed

We also measured, using the CAT assay, the effect of TNF or IL-1 $\beta$ inhibition on procoagulant activities of NB4 cells and NB4 cell-derived microparticles. With anti-TNF, we only observed a small significant increase in lag time and a decrease in peak height for NB4 microparticles but no effect on area under the curve (Fig. 4b). Treatment with anakinra had no significant effect on any of the parameters of the CAT assay (Fig. 4b).

\section{Effect of inflammatory signaling intermediates on expression of TF, TNF, and IL-1 $\beta$ by NB4 cells}

TNF and IL-1 $\beta$ exert their proinflammatory effects by signaling intermediates including p38 MAP kinase, jun kinase (JNK), and NF-KB. Inhibition of p38 with $10 \mu \mathrm{M}$ of SB202190, Birb796, or SB203580 reduced TF mRNA in NB4 cells by $19 \pm 4 \%, 26 \pm 10 \%$, and $38 \pm 11 \%$, respectively (Fig. 6). In contrast, these p38 inhibitors increased mRNA of TNF and IL-1 $\beta$ (Fig. 6). The strongest effect was seen with SB202190, which increased TNF mRNA and IL-1 $\beta$ mRNA by $6.2 \pm 1.3$-fold and $26.1 \pm 4.1$-fold, respectively. An intermediate effect was seen with SB203580 with a $4.9 \pm 0.7$ and

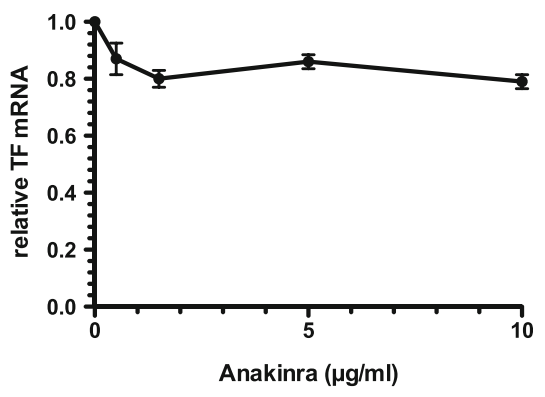

relative to that of the corresponding mRNA in control (unexposed cells, incubated in medium alone) NB4 cells. Results are expressed as means \pm SEM of six independent experiments

$7.1 \pm 0.5$-fold increase in TNF and IL- $1 \beta$ mRNA, respectively, and the smallest effect with Birb796 with a $2.2 \pm 0.3$ and $3.1 \pm 1.0$ increase in TNF and IL-1 $\beta$ mRNA, respectively. Inhibition of JNK, using $10 \mu \mathrm{M}$ of SP600125, had no effect on TF mRNA and reduced TNF and IL- $1 \beta$ mRNA by $31 \pm 11 \%$ and $80 \pm 2 \%$, respectively (Fig. 6). We also measured, using the CAT assay, the effect of the p38 inhibitor SB203580 on procoagulant activities of NB4 cells and NB4 cell-derived microparticles. No significant changes in lag time, peak height, and area under the curve were observed (Fig. 4b).

Inhibition of NF- $\mathrm{KB}$, using $100 \mu \mathrm{M}$ of BAY11-7085, led to a very rapid reduction in TF and TNF mRNA. Minimal levels were observed already after $1 \mathrm{~h}$ (49\% and $42 \%$, respectively; Supplementary Fig. 1). BAY11-7085 had no effect on IL-1 $\beta$ mRNA. An unexpected finding was that BAY11-7085 had a strong effect on cell survival. After $6 \mathrm{~h}$ incubation with $100 \mu \mathrm{M}$ of BAY11-7085, NB4 cell survival was only $42 \%$, as compared to over $95 \%$ for untreated NB4 cells and after $24 \mathrm{~h}$ cell survival was less than $10 \%$. In view of this, mRNA measurements are shown only for the time period up to $2 \mathrm{~h}$. Incubation of NB4 cells for $24 \mathrm{~h}$ with BAY11-7085 had no
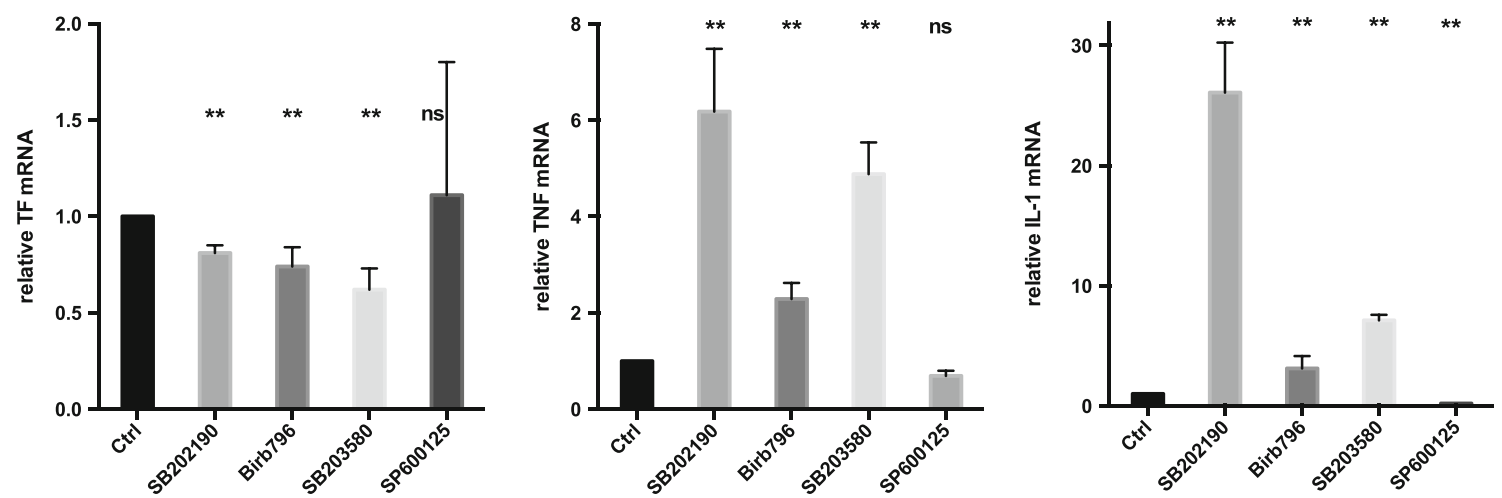

Fig. 6 Effect of inhibition of p38 or jun kinase on mRNA levels of TF, TNF, or IL-1 $\beta$ in NB4 cells. NB4 cells were exposed for $24 \mathrm{~h}$ to $10 \mu \mathrm{M}$ of the p38 inhibitors SB202190, Birb796, or SB203580 or $10 \mu \mathrm{M}$ of the jun kinase inhibitor SP600126 and mRNA levels of TF, TNF, or IL-1 $\beta$ quantified by qPCR and expressed relative to that of the corresponding
mRNA in control (unexposed cells, incubated in medium alone) NB4 cells. Results are expressed as means \pm SEM of six independent experiments. Results obtained with the $\mathrm{p} 38$ inhibitors are significant with a $p$ value $<0.01$ 
effect on procoagulant activities of NB4 cells, as measured with the CAT assay, but reduced the lag time of and increased peak height NB4 cell-derived microparticles (Fig. 4b).

\section{Discussion}

Human APL cells produce both TF and the inflammatory cytokines TNF and IL-1 $\beta$. This study was undertaken to investigate the effect of ATRA and ATO on the expression of these proteins and to better understand the contribution of the inflammatory cytokines TNF and IL- $1 \beta$, as well as the signaling intermediates $\mathrm{p} 38, \mathrm{JNK}$, and NF- $\mathrm{KB}$ to $\mathrm{TF}$ expression by APL cells. For this, we used the NB4 human APL cell line, which has the $15 ; 17$ chromosomal translocation leading to the production of the PML-RAR $\alpha$ fusion protein [36], that is characteristic for the majority of acute promyelocytic leukemia cases [37]. NB4 cells were chosen for this study, because the behavior of these cells was shown, in many studies, to be comparable to that of patient-derived primary APL cells [12, 18, 34, 38-44]. We also analyzed the effect of ATRA and ATO in HL-60 acute myeloid leukemia cells which lacks the 15;17 translocation [45]. Our results in NB4 cells show that ATRA and ATO reduce TF and TNF mRNA but increase IL- $1 \beta$ mRNA; that at the NB4 cell concentrations used $\left(10^{6}\right.$ cells/ $\mathrm{ml}), \mathrm{TNF}$ and to a lesser extent IL- $1 \beta$ partially contribute to TF expression; and that NF-KB and $\mathrm{p} 38$ contribute to TF expression. Our results that ATRA reduces TF mRNA and activity in NB4 cells are in agreement with previous results using this cell line [18, 20-22] and with results obtained with bone marrow cells from APL patients at different times after initiation of ATRA treatment [7, 19, 27]. ATRA and ATO both have similar effects on TF mRNA. However, ATRA reduces by $90 \%$ already within $1 \mathrm{~h}$, whereas the effect of ATO on TF mRNA is evident only after $6 \mathrm{~h}$.

In HL-60 cells, which lack the 15;17 chromosomal translocation, ATRA acted more slowly on TF mRNA and a maximal of $35 \%$ inhibition was obtained after $3 \mathrm{~h}$, whereas ATO increased TF mRNA up to twofold. This implies that the effect of ATRA and ATO on TF expression is different in NB4 and HL-60 cells.

In NB4 cells, both ATRA and ATO induce the degradation of the PML-RAR $\alpha$ fusion protein [32], which is capable of stimulating an increased TF expression [18]. Our finding that $\mathrm{Zn}^{2+}$ stimulation of U937-PR9 cells strongly increases TF and TNF mRNA (Fig. 2) and that ATO treatment of these $\mathrm{Zn}^{2+}$ stimulated cells reduced TF mRNA is compatible with the hypothesis that ATRA and ATO reduced TF and TNF via the degradation of PML-RAR $\alpha$. However, the increase in IL-1 $\beta$ also induced by $\mathrm{Zn}^{2+}$ stimulation of U937-PR9 cells (Fig. 2) contrasts with the fact that neither ATRA nor ATO reduced this cytokine. In addition, the rapidity of the effect of ATRA on TF expression rather suggests a primary action that is independent of PML-RAR $\alpha$ degradation. Indeed, one hypothesis for APL pathogenesis suggests that PML/RAR $\alpha$ recruits co-repressors and histone deacetylases to their putative target genes at physiological concentrations of ATRA [46, 47]. A primary effect of ATRA at pharmacological concentrations is to change the PML-RAR $\alpha$ fusion protein from a repressor into a transcriptional activator [48]. It is therefore likely that the effect of ATRA on TF reduction is not direct but rather related to upregulation of a protein that negatively regulates TF expression. The rapid ATRA-induced reduction in TF mRNA, with a half-life of less than $1 \mathrm{~h}$, is compatible with the short TF mRNA half-life previously described for TNFstimulated endothelial cells [49]. A plausible mechanism for the effect of ATRA would therefore be an increase in TF mRNA turnover rather than a mechanism dependent on PML-RAR $\alpha$ degradation; the latter may be relevant after ATO treatment. The rapid turnover of TF mRNA may involve an AU-rich element (ARE) in the TF mRNA molecule, which is known to recruit RNA-degrading enzymes [50]. Indeed, ARE interacting proteins such as tristetraprolin and PARP14 exert selective posttranscriptional control of TF in macrophages [51, 52].

We complemented our analysis on TF mRNA with assays of procoagulant activity of NB4 cells and of NB4 cell-derived microparticles. Several lines of evidence point to a role of microparticles emitted by leukemic cells in the disturbances of hemostasis [13, 14, 53]. These microparticles may exert a direct or an indirect procoagulant effect. Indeed, Fang et al. [54] have shown that vascular endothelial cells may uptake NB4-derived microparticles and microparticle-derived TF may make the endothelial cells procoagulant. Coagulation studies were not only the chromogenic factor Xa generation assay but also the CAT assay $[35,55]$. The latter is thought to be more relevant to the in vivo phenomena, because it takes into account all factors that contribute to the pro- and anticoagulant activities of NB4 cells and microparticles [56]. The effect of ATRA on TF protein and activity is delayed with respect to its rapid effect on TF mRNA and is only evident at $24 \mathrm{~h}$. Even then, significant procoagulant activity is still detected and this information is quite relevant in the context of reducing hemorrhagic complication in the early treatment phase [57]. In agreement with previous reports [58, 59], we found with the CAT assay that cells and microparticles bring both TF and an appropriate surface, since a substantial inhibition was obtained in presence of anti-TF antibody and since we did not add extra phospholipids. Of note, inhibition of thrombin generation as assessed with the CAT assay appeared to be less than that measured with the artificial Xa generation assay. This underscores the importance to assay TF activity under more physiological conditions.

Exposure of NB4 cells to ATRA resulted in a reduction of TNF mRNA, as well as an increase in IL- $1 \beta$ mRNA. There are previous reports on the absence of an effect of ATRA on 
TNF mRNA [24, 25]. It remains to be established whether the difference in effect of ATRA is due to differences in timing of TNF mRNA measurements (up to $24 \mathrm{~h}$ versus 2 to 4 days) or in ATRA concentration $(0.5$ versus $10 \mu \mathrm{M})$. On the other hand, the ATRA-induced increase in IL- $1 \beta$ expression is in agreement with previous reports $[24,25]$. The effect of ATRA in reducing TNF mRNA appears to be specific for NB4 cells, because ATRA treatment of HL60 acute myeloid leukemia cells had no effect on TNF mRNA (this study) or increased TNF mRNA [24]. TNF is known to increase TF expression in different cell types. The ATRA-induced reduction of TNF mRNA occurs later than that of TF mRNA (several hours versus $30 \mathrm{~min}$ ). Therefore, the decrease in TNF expression cannot explain the effect of ATRA on TF mRNA.

However, TNF does contribute, at least partially, to TF expression in NB4 cells because inhibition of TNF by using adalimumab consistently reduced in TF mRNA by $25 \%$ and reduced the procoagulant activity of NB4 cells and NB4 cellderived microparticles. The contribution of IL- $1 \beta$ to TF mRNA was less than that of TNF, and we could not detect an effect of IL-1 $\beta$ inhibition on CAT activity expressed by NB4 cells and NB4 cell-derived microparticles. In APL patients, the contribution of TNF or of IL- $1 \beta$ may be higher because NB4 cell densities used in our experiments are much lower than the densities of leukemic cells encountered in patient's blood and bone marrow. We were unable to study the contribution of TNF or of IL- $1 \beta$ at higher cell concentrations because, in our in vitro cell culture system, these are limited to approximately $10^{6} \mathrm{NB} 4$ cells/ml due to acidification and exhaustion of the cell culture medium within $24 \mathrm{~h}$. Leukemia cell-derived cytokines may also be relevant for thrombo-hemorrhagic events in APL patients, because they increase TF expression by endothelial cells [60-62] and monocytes [63].

We observed that inhibition of the signaling intermediates p38 or of NF- $\kappa$ B that act downstream of TNF or IL- $1 \beta$ had a more pronounced effect (38\% and $62 \%$ inhibition of $\mathrm{TF}$ mRNA, respectively), than selective inhibition of TNF or IL- $1 \beta$ alone $(28 \%$ and $20 \%$ inhibition of TF mRNA, respectively), whereas inhibition of jun kinase had no effect. However, it has to be stressed that inhibition of $\mathrm{p} 38$ results in a strong increase in TNF expression (sixfold) and an even more pronounced increase in IL-1 $\beta$ expression (26-fold). Thus, it appears that key elements of the signaling pathways of inflammatory cytokines are also involved in the regulation of their production. An unexpected finding of our study was that inhibition of NF-KB induced cell death within a few hours. The resulting liberation of TF-bearing microparticles may explain the increase in procoagulant activity of NB4 cell-derived microparticles, as measured with the CAT assay, despite an initial reduction in TF mRNA.

The effect of NF- $\mathrm{KB}$ inhibition should stimulate more detailed studies on the importance of NF-KB for APL cell survival, the mechanisms by which NF- $\mathrm{KB}$ inhibition induces cell death and whether NF- $\kappa B$ inhibition can be used as adjunct therapy in APL $[64,65]$. The consequences of potential effects of NF- $\mathrm{KB}$ inhibition on APL cell survival should be carefully evaluated, as the apoptotic cells and the cell-derived microparticles express phosphatidylserine at their surface and may thereby exacerbate thrombo-hemorrhagic complications, despite an initial reduction in TF mRNA, but not yet in TF protein.

In conclusion, ATRA and ATO reduce expression by NB4 APL cells of both TF and TNF and inhibition of TNF or IL-1 $\beta$ or of the inflammatory signaling intermediates $\mathrm{p} 38$ or $\mathrm{NF}-\mathrm{KB}$ also reduces TF.

Thus, TNF and IL-1 $\beta$ have a regulatory function on TF expression by NB4 APL cells, but the effect of ATRA and ATO on TF can only partially be accounted for their impact on these cytokines. The results presented here should stimulate further in vitro and in vivo preclinical studies to determine to what extent inhibition of inflammatory cytokines or inflammatory signaling intermediates can be used for the further development of adjunct therapies of APL.

Acknowledgements This work was supported by grants from "Swiss Cancer Research," the "Fondation Dr Henri Dubois-Ferrière Dinu Lipatti," the "Ligue Genevoise contre le Cancer," and the ISTH 2007 Presidential Fund.

We also acknowledge Céline Fickentscher and Cuong An Do for their technical help.

Author contributions SDG, OT, TL, and EKOK conceived and designed the project. SDG, ASRC, and EKOK performed the experiments and analyzed the data. SDG, OT, TL, and EKOK wrote and finalized the paper.

\section{Compliance with ethical standards}

Conflict of interest The authors declare that they have no conflict of interest.

Open Access This article is distributed under the terms of the Creative Commons Attribution 4.0 International License (http:// creativecommons.org/licenses/by/4.0/), which permits unrestricted use, distribution, and reproduction in any medium, provided you give appropriate credit to the original author(s) and the source, provide a link to the Creative Commons license, and indicate if changes were made.

\section{References}

1. Yanada M, Matsushita T, Asou N, Kishimoto Y, Tsuzuki M, Maeda Y, Horikawa K, Okada M, Ohtake S, Yagasaki F, Matsumoto T, Kimura Y, Shinagawa K, Iwanaga M, Miyazaki Y, Ohno R, Naoe T (2007) Severe hemorrhagic complications during remission induction therapy for acute promyelocytic leukemia: incidence, risk factors, and influence on outcome. Eur J Haematol 78(3):213-219. doi:10.1111/j.1600-0609.2006.00803.x

2. de la Serna J, Montesinos P, Vellenga E, Rayon C, Parody R, Leon A, Esteve J, Bergua JM, Milone G, Deben G, Rivas C, Gonzalez M, 
Tormo M, Diaz-Mediavilla J, Gonzalez JD, Negri S, Amutio E, Brunet S, Lowenberg B, Sanz MA (2008) Causes and prognostic factors of remission induction failure in patients with acute promyelocytic leukemia treated with all-trans retinoic acid and idarubicin. Blood 111(7):3395-3402. doi:10.1182/blood-2007-07100669

3. Stein E, McMahon B, Kwaan H, Altman JK, Frankfurt O, Tallman MS (2009) The coagulopathy of acute promyelocytic leukaemia revisited. Best Pract Res Clin Haematol 22(1):153-163. doi:10. 1016/j.beha.2008.12.007

4. Sanz MA, Montesinos P (2010) Open issues on bleeding and thrombosis in acute promyelocytic leukemia. Thromb Res 125(Suppl 2):S51-S54. doi:10.1016/S0049-3848(10)70013-X

5. Breccia M, Lo Coco F (2014) Thrombo-hemorrhagic deaths in acute promyelocytic leukemia. Thromb Res 133(Suppl 2):S112 S116. doi:10.1016/S0049-3848(14)50019-9

6. Micol JB, Raffoux E, Boissel N, Lengline E, Canet E, Daniel MT, Labarthe A, Maarek O, Cassinat B, Ades L, Baruchel A, Degos L, Azoulay E, Dombret H (2014) Management and treatment results in patients with acute promyelocytic leukaemia (APL) not enrolled in clinical trials. Eur J Cancer 50(6):1159-1168. doi:10.1016/j.ejca. 2013.11.023

7. Zhao W, Wang H, Wang X, Wu F, Guo W, Qu B, Shen Z, Wang Z (2001) Effects of all-trans-retinoic acid and arsenic trioxide on the hemostatic disturbance associated with acute promyelocytic leukemia. Thromb Res 102(3):197-204

8. Tallman MS, Lefebvre P, Baine RM, Shoji M, Cohen I, Green D, Kwaan HC, Paietta E, Rickles FR (2004) Effects of all-trans retinoic acid or chemotherapy on the molecular regulation of systemic blood coagulation and fibrinolysis in patients with acute promyelocytic leukemia. Journal of thrombosis and haemostasis: JTH 2(8):1341-1350. doi:10.1111/j.1538-7836.2004.00787.x

9. Chang H, Kuo MC, Shih LY, Dunn P, Wang PN, Wu JH, Lin TL, Hung YS, Tang TC (2012) Clinical bleeding events and laboratory coagulation profiles in acute promyelocytic leukemia. Eur J Haematol 88(4):321-328. doi:10.1111/j.1600-0609.2011.01747.x

10. Distler JH, Huber LC, Hueber AJ, Reich CF 3rd, Gay S, Distler O, Pisetsky DS (2005) The release of microparticles by apoptotic cells and their effects on macrophages. Apoptosis: an international journal on programmed cell death 10(4):731-741. doi:10.1007/s10495005-2941-5

11. Langer F, Spath B, Haubold K, Holstein K, Marx G, Wierecky J, Brummendorf TH, Dierlamm J, Bokemeyer C, Eifrig B (2008) Tissue factor procoagulant activity of plasma microparticles in patients with cancer-associated disseminated intravascular coagulation. Ann Hematol 87(6):451-457. doi:10.1007/s00277-0080446-3

12. Zhou J, Shi J, Hou J, Cao F, Zhang Y, Rasmussen JT, Heegaard CW, Gilbert GE (2010) Phosphatidylserine exposure and procoagulant activity in acute promyelocytic leukemia. Journal of thrombosis and haemostasis: JTH 8(4):773-782. doi:10.1111/j.1538-7836.2010. 03763.x

13. Kwaan HC, Rego EM (2010) Role of microparticles in the hemostatic dysfunction in acute promyelocytic leukemia. Semin Thromb Hemost 36(8):917-924. doi:10.1055/s-0030-1267045

14. Ma G, Liu F, Lv L, Gao Y, Su Y (2013) Increased promyelocyticderived microparticles: a novel potential factor for coagulopathy in acute promyelocytic leukemia. Ann Hematol 92(5):645-652. doi: 10.1007/s00277-013-1676-6

15. Menell JS, Cesarman GM, Jacovina AT, McLaughlin MA, Lev EA, Hajjar KA (1999) Annexin II and bleeding in acute promyelocytic leukemia. N Engl J Med 340(13):994-1004. doi:10.1056/ NEJM199904013401303

16. Falanga A, Iacoviello L, Evangelista V, Belotti D, Consonni R, D’Orazio A, Robba L, Donati MB, Barbui T (1995) Loss of blast cell procoagulant activity and improvement of hemostatic variables in patients with acute promyelocytic leukemia administered alltrans-retinoic acid. Blood 86(3):1072-1081

17. Dombret H, Scrobohaci ML, Daniel MT, Miclea JM, Castaigne S, Chomienne C, Fenaux P, Degos L (1995) In vivo thrombin and plasmin activities in patients with acute promyelocytic leukemia (APL): effect of all-trans retinoic acid (ATRA) therapy. Leukemia: official journal of the Leukemia Society of America, Leukemia Research Fund, UK 9(1):19-24

18. Guo W, Wang H, Zhao W, Zhu J, Ju B, Wang X (2001) Effect of alltrans retinoic acid and arsenic trioxide on tissue factor expression in acute promyelocytic leukemia cells. Chin Med J 114(1):30-34

19. De Stefano V, Teofili L, Sica S, Mastrangelo S, Di Mario A, Rutella S, Salutari P, Rumi C, d'Onofrio G, Leone G (1995) Effect of alltrans retinoic acid on procoagulant and fibrinolytic activities of cultured blast cells from patients with acute promyelocytic leukemia. Blood 86(9):3535-3541

20. Koyama T, Hirosawa S, Kawamata N, Tohda S, Aoki N (1994) Alltrans retinoic acid upregulates thrombomodulin and downregulates tissue-factor expression in acute promyelocytic leukemia cells: distinct expression of thrombomodulin and tissue factor in human leukemic cells. Blood 84(9):3001-3009

21. Zhu J, Guo WM, Yao YY, Zhao WL, Pan L, Cai X, Ju B, Sun GL, Wang HL, Chen SJ, Chen GQ, Caen J, Chen Z, Wang ZY (1999) Tissue factors on acute promyelocytic leukemia and endothelial cells are differently regulated by retinoic acid, arsenic trioxide and chemotherapeutic agents. Leukemia: official journal of the Leukemia Society of America, Leukemia Research Fund, UK 13(7):1062-1070

22. Tenno T, Oberg F, Nilsson K, Siegbahn A (1999) Induction of differentiation in U-937 and NB4 cells is associated with inhibition of tissue factor production. Eur J Haematol 63(2):112-119

23. Tsai WH, Chien HY, Shih CH, Lai SL, Li IT, Hsu SC, Kou YR, Hsu HC (2012) Annexin A1 mediates the anti-inflammatory effects during the granulocytic differentiation process in all-trans retinoic acidtreated acute promyelocytic leukemic cells. J Cell Physiol 227(11): 3661-3669. doi:10.1002/jcp. 24073

24. Gianni M, Norio P, Terao M, Falanga A, Marchetti M, Rambaldi A, Garattini E (1995) Effects of dexamethasone on pro-inflammatory cytokine expression, cell growth and maturation during granulocytic differentiation of acute promyelocytic leukemia cells. Eur Cytokine Netw 6(3):157-165

25. Hsu HC, Tsai WH, Chen PG, Hsu ML, Ho CK, Wang SY (1999) In vitro effect of granulocyte-colony stimulating factor and all-trans retinoic acid on the expression of inflammatory cytokines and adhesion molecules in acute promyelocytic leukemic cells. Eur J Haematol 63(1):11-18

26. Ismair MG, Ries C, Lottspeich F, Zang C, Kolb HJ, Petrides PE (1998) Autocrine regulation of matrix metalloproteinase-9 gene expression and secretion by tumor necrosis factor-alpha (TNF-alpha) in NB4 leukemic cells: specific involvement of TNF receptor type 1. Leukemia: official journal of the Leukemia Society of America, Leukemia Research Fund, UK 12(7):1136-1143

27. Grignani F, Ferrucci PF, Testa U, Talamo G, Fagioli M, Alcalay M, Mencarelli A, Grignani F, Peschle C, Nicoletti I et al (1993) The acute promyelocytic leukemia-specific PML-RAR alpha fusion protein inhibits differentiation and promotes survival of myeloid precursor cells. Cell 74(3):423-431

28. Fish RJ, Kruithof EK (2004) Short-term cytotoxic effects and longterm instability of RNAi delivered using lentiviral vectors. BMC Mol Biol 5:9. doi:10.1186/1471-2199-5-9

29. Satta N, Toti F, Feugeas O, Bohbot A, Dachary-Prigent J, Eschwege V, Hedman H, Freyssinet JM (1994) Monocyte vesiculation is a possible mechanism for dissemination of membrane-associated procoagulant activities and adhesion molecules after stimulation by lipopolysaccharide. J Immunol 153(7):3245-3255 
30. Hemker HC, Giesen P, AlDieri R, Regnault V, de Smed E, Wagenvoord R, Lecompte T, Beguin S (2002) The calibrated automated thrombogram (CAT): a universal routine test for hyperand hypocoagulability. Pathophysiol Haemost Thromb 32(5-6): 249-253. doi:10.1159/000073575

31. Pouplard C, Reverdiau-Moalic P, Piquemal R, Watier H, Lebranchu Y, Bardos P, Gruel Y (1995) A simplified and low-cost one-stage chromogenic assay for tissue factor dependent procoagulant activity of endothelial cells. Thromb Res 80(6):527-534

32. de The H, Chen Z (2010) Acute promyelocytic leukaemia: novel insights into the mechanisms of cure. Nat Rev Cancer 10(11):775783. doi: $10.1038 / \mathrm{nrc} 2943$

33. Lopez-Pedrera C, Barbarroja N, Buendia P, Torres A, Dorado G, Velasco F (2004) Promyelocytic leukemia retinoid signaling targets regulate apoptosis, tissue factor and thrombomodulin expression. Haematologica 89(3):286-295

34. Ikezoe T, Yang J, Nishioka C, Isaka M, Iwabu N, Sakai M, Taniguchi A, Honda G, Yokoyama A (2012) Thrombomodulin enhances the antifibrinolytic and antileukemic effects of all-trans retinoic acid in acute promyelocytic leukemia cells. Exp Hematol 40(6):457-465. doi:10.1016/j.exphem.2012.01.016

35. Marchetti M, Diani E, ten Cate H, Falanga A (2012) Characterization of the thrombin generation potential of leukemic and solid tumor cells by calibrated automated thrombography. Haematologica 97(8):1173-1180. doi:10.3324/haematol.2011. 055343

36. Lanotte M, Martin-Thouvenin V, Najman S, Balerini P, Valensi F, Berger R (1991) NB4, a maturation inducible cell line with $\mathrm{t}(15 ; 17)$ marker isolated from a human acute promyelocytic leukemia (M3). Blood 77(5):1080-1086

37. Larson RA, Kondo K, Vardiman JW, Butler AE, Golomb HM, Rowley JD (1984) Evidence for a 15;17 translocation in every patient with acute promyelocytic leukemia. Am J Med 76(5):827-841

38. Zassadowski F, Pokorna K, Ferre N, Guidez F, Llopis L, Chourbagi O, Chopin M, Poupon J, Fenaux P, Ann Padua R, Pla M, Chomienne C, Cassinat B (2015) Lithium chloride antileukemic activity in acute promyelocytic leukemia is GSK-3 and MEK/ ERK dependent. Leukemia: official journal of the Leukemia Society of America, Leukemia Research Fund, UK 29(12):22772284. doi:10.1038/leu.2015.159

39. Wang S, Zhou M, Ouyang J, Geng Z, Wang Z (2015) Tetraarsenictetrasulfide and arsenic trioxide exert synergistic effects on induction of apoptosis and differentiation in acute promyelocytic leukemia cells. PLoS One 10(6):e0130343. doi: 10.1371/journal.pone. 0130343

40. Heo SK, Noh EK, Yoon DJ, Jo JC, Koh S, Baek JH, Park JH, Min YJ, Kim H (2015) Rosmarinic acid potentiates ATRA-induced macrophage differentiation in acute promyelocytic leukemia NB4 cells. Eur J Pharmacol 747:36-44. doi:10.1016/j.ejphar.2014.10. 064

41. Xie R, Gao C, Li W, Zhu J, Novakovic V, Wang J, Ma R, Zhou J, Gilbert GE, Shi J (2012) Phagocytosis by macrophages and endothelial cells inhibits procoagulant and fibrinolytic activity of acute promyelocytic leukemia cells. Blood 119(10):2325-2334. doi:10. 1182/blood-2011-06-362186

42. Saumet A, Vetter G, Bouttier M, Portales-Casamar E, Wasserman WW, Maurin T, Mari B, Barbry P, Vallar L, Friederich E, Arar K, Cassinat B, Chomienne C, Lecellier CH (2009) Transcriptional repression of microRNA genes by PML-RARA increases expression of key cancer proteins in acute promyelocytic leukemia. Blood 113(2):412-421. doi:10.1182/blood-2008-05-158139

43. Luesink M, Pennings JL, Wissink WM, Linssen PC, Muus P, Pfundt R, de Witte TJ, van der Reijden BA, Jansen JH (2009) Chemokine induction by all-trans retinoic acid and arsenic trioxide in acute promyelocytic leukemia: triggering the differentiation syndrome. Blood 114(27):5512-5521. doi:10.1182/blood-200902-204834

44. Iriyama N, Yuan B, Yoshino Y, Hatta Y, Horikoshi A, Aizawa S, Takeuchi J, Toyoda H (2013) Aquaporin 9, a promising predictor for the cytocidal effects of arsenic trioxide in acute promyelocytic leukemia cell lines and primary blasts. Oncol Rep 29(6):23622368. doi:10.3892/or.2013.2388

45. Drexler HG, Quentmeier H, MacLeod RA, Uphoff CC, Hu ZB (1995) Leukemia cell lines: in vitro models for the study of acute promyelocytic leukemia. Leuk Res 19(10):681-691

46. Grignani F, De Matteis S, Nervi C, Tomassoni L, Gelmetti V, Cioce M, Fanelli M, Ruthardt M, Ferrara FF, Zamir I, Seiser C, Grignani F, Lazar MA, Minucci S, Pelicci PG (1998) Fusion proteins of the retinoic acid receptor-alpha recruit histone deacetylase in promyelocytic leukaemia. Nature 391(6669):815-818. doi:10. $1038 / 35901$

47. Lin RJ, Nagy L, Inoue S, Shao W, Miller WH Jr, Evans RM (1998) Role of the histone deacetylase complex in acute promyelocytic leukaemia. Nature 391(6669):811-814. doi:10.1038/35895

48. Melnick A, Licht JD (1999) Deconstructing a disease: RARalpha, its fusion partners, and their roles in the pathogenesis of acute promyelocytic leukemia. Blood 93(10):3167-3215

49. Scarpati EM, Sadler JE (1989) Regulation of endothelial cell coagulant properties. Modulation of tissue factor, plasminogen activator inhibitors, and thrombomodulin by phorbol 12-myristate 13-acetate and tumor necrosis factor. J Biol Chem 264(34):20705-20713

50. Ahern SM, Miyata T, Sadler JE (1993) Regulation of human tissue factor expression by mRNA turnover. J Biol Chem 268(3):2154 2159

51. Iqbal MB, Johns M, Cao J, Liu Y, Yu SC, Hyde GD, Laffan MA, Marchese FP, Cho SH, Clark AR, Gavins FN, Woollard KJ, Blackshear PJ, Mackman N, Dean JL, Boothby M, Haskard DO (2014) PARP-14 combines with tristetraprolin in the selective posttranscriptional control of macrophage tissue factor expression. Blood 124(24):3646-3655. doi:10.1182/blood-2014-07-588046

52. Qiu LQ, Lai WS, Bradbury A, Zeldin DC, Blackshear PJ (2015) Tristetraprolin (TTP) coordinately regulates primary and secondary cellular responses to proinflammatory stimuli. J Leukoc Biol 97(4): 723-736. doi:10.1189/jlb.3A0214-106R

53. Gheldof D, Chatelain C, Dogne JM, Mullier F (2014) Microparticle-associated tissue factor activity and overt disseminated intravascular coagulation in patients with acute myelocytic leukemia. Thromb Res 134(1):213-214. doi:10.1016/j.thromres. 2014.05.001

54. Fang Y, Garnier D, Lee TH, D'Asti E, Montermini L, Meehan B, Rak J (2016) PML-RARa modulates the vascular signature of extracellular vesicles released by acute promyelocytic leukemia cells. Angiogenesis 19(1):25-38. doi:10.1007/s10456-015-9486-1

55. Dargaud Y, Wolberg AS, Luddington R, Regnault V, Spronk H, Baglin T, Lecompte T, Ten Cate H, Negrier C (2012) Evaluation of a standardized protocol for thrombin generation measurement using the calibrated automated thrombogram: an international multicentre study. Thromb Res 130(6):929-934. doi:10.1016/j. thromres.2012.07.017

56. Ten Cate H (2012) Thrombin generation in clinical conditions. Thromb Res 129(3):367-370. doi:10.1016/j.thromres.2011.10.017

57. Park JH, Qiao B, Panageas KS, Schymura MJ, Jurcic JG, Rosenblat TL, Altman JK, Douer D, Rowe JM, Tallman MS (2011) Early death rate in acute promyelocytic leukemia remains high despite all-trans retinoic acid. Blood 118(5):1248-1254. doi:10.1182/ blood-2011-04-346437

58. Falanga A, Consonni R, Marchetti M, Locatelli G, Garattini E, Passerini CG, Gordon SG, Barbui T (1998) Cancer procoagulant and tissue factor are differently modulated by all-trans-retinoic acid in acute promyelocytic leukemia cells. Blood 92(1):143-151 
59. Tormoen GW, Recht O, Gruber A, Levine RL, McCarty OJ (2013) Phosphatidylserine index as a marker of the procoagulant phenotype of acute myelogenous leukemia cells. Phys Biol 10(5):056010. doi:10.1088/1478-3975/10/5/056010

60. Bevilacqua MP, Pober JS, Majeau GR, Fiers W, Cotran RS, Gimbrone MA Jr (1986) Recombinant tumor necrosis factor induces procoagulant activity in cultured human vascular endothelium: characterization and comparison with the actions of interleukin 1. Proc Natl Acad Sci U S A 83(12):4533-4537

61. Nawroth PP, Stern DM (1986) Modulation of endothelial cell hemostatic properties by tumor necrosis factor. J Exp Med 163(3): 740-745

62. Levi M, ten Cate H, Bauer KA, van der Poll T, Edgington TS, Buller HR, van Deventer SJ, Hack CE, ten Cate JW, Rosenberg RD (1994) Inhibition of endotoxin-induced activation of coagulation and fibrinolysis by pentoxifylline or by a monoclonal anti-tissue factor antibody in chimpanzees. J Clin Invest 93(1):114 120. doi:10.1172/JCI116934

63. Conkling PR, Greenberg CS, Weinberg JB (1988) Tumor necrosis factor induces tissue factor-like activity in human leukemia cell line U937 and peripheral blood monocytes. Blood 72(1):128-133

64. Morales-Cano D, Calvino E, Rubio V, Herraez A, Sancho P, Tejedor MC, Diez JC (2013) Apoptosis induced by paclitaxel via Bcl-2, Bax and caspases 3 and 9 activation in NB4 human leukaemia cells is not modulated by ERK inhibition. Exp Toxicol Pathol 65(7-8):1101-1108. doi:10.1016/j.etp.2013.04.006

65. Fatemi A, Safa M, Kazemi A (2015) MST-312 induces G2/M cell cycle arrest and apoptosis in APL cells through inhibition of telomerase activity and suppression of NF-kappaB pathway. Tumour Biol 36(11):8425-8437. doi:10.1007/s13277-015-3575-Z 